\title{
Cloning and characterization of Vasa gene expression pattern in adults of the Lusitanian toadfish Halobatrachus didactylus
}

\author{
María Úbeda-Manzanaro ${ }^{1, *}$, Laureana Rebordinos $^{2}$, Carmen Sarasquete $^{1}$ \\ ${ }^{1}$ Institute of Marine Sciences of Andalusia (ICMAN-CSIC), University Campus, 11519 Puerto Real, Cadiz, Spain \\ ${ }^{2}$ Laboratory of Genetics, Faculty of Marine and Environmental Sciences, University of Cadiz, Campus Rio San Pedro, \\ 11510 Puerto Real, Spain
}

\begin{abstract}
The Vasa gene is essential for germ cell development in eukaryotes. It encodes a RNA helicase, a member of the DEAD box protein family. Using the RACE method, we cloned the Vasa cDNA of the Lusitanian toadfish Halobatrachus didactylus, and analyzed quantitative and qualitative Vasa expression and its protein immunolocalization. We reported a main product of about $2.4 \mathrm{~kb}$ which encodes a protein of 615 amino acids, but other minority Vasa products were also identified by RACE-PCR. This gene is predominantly expressed in the ovaries and testes, although some relatively low extragonadal expression levels have also been identified. In situ hybridization and immunolocalization analysis during gametogenesis in the testes showed that toadfish Vasa mRNA was detected in spermatogonia, spermatocytes and spermatids. However, in the ovaries, Vasa mRNA was detected in early vitellogenic oocytes and in more advanced vitellogenic stages, showing a very weak signal in oogonia, whereas the Vasa protein was evidenced in the cytoplasm of oogonia and previtellogenic oocytes, becoming weaker as the vitellogenic and maturation processes progress. These results suggest that toadfish Vasa homologues can play an important role in gametogenesis and germ cell development, but it could also be functionally implicated in other processes that are not as well known.
\end{abstract}

KEY WORDS: Expression pattern - Immunochemistry · In situ hybridization - Oogenesis · Spermatogenesis · Toadfish · Vasa

\section{INTRODUCTION}

The Lusitanian toadfish Halobatrachus didactylus (Bloch \& Schneider, 1801) belongs to the family Batrachoididae (Order Batrachoidiformes), a small group of fish known as toadfish that contains over 78 species occurring worldwide, with 25 genera and 4 subfamilies (Greenfield et al. 2008). This species is distributed on the eastern coast of the Atlantic Ocean, from the Bay of Biscay (Spain) to Ghana, and on the western Mediterranean coast, and it is the only species of this family found in European waters. The spawning season of $H$. didactylus extends from March to August, with a peak in May-June (Palazón-

\footnotetext{
${ }^{*}$ Corresponding author: mariaubeda.manzanaro@icman.csic.es
}

Fernández et al. 2001). H. didactylus does not have a high commercial value in southwestern European countries, but it has been employed in many multidisciplinary studies, such as biology, haematology, toxicology and ecology as well as for experimental cardiological purposes (Borges et al. 2003, Campana et al. 2003, Desantis et al. 2007, Soares et al. 2008, Palazón-Fernández et al. 2011, Vasconcelos et al. 2011). In addition, different aspects of reproduction have been studied in H. didactylus (Palazón-Fernández et al. 2001, Modesto \& Canário 2003). Recently, cytogenetic and molecular studies have been carried out (Merlo et al. 2007, Úbeda-Manzanaro et al. 2014) in Batrachoididae fish species, which are considered

(C) The authors 2014. Open Access under Creative Commons by Attribution Licence. Use, distribution and reproduction are unrestricted. Authors and original publication must be credited. 
one of the most highly evolved groups of marine teleosts (Modesto \& Canário 2003).

The Vasa gene, also called $D d x 4$, is an ATP-dependent RNA helicase belonging to the DEAD (Asp-GluAla-Asp)-box protein family, the largest family of helicases. These helicases are broadly conserved across all phyla, are involved in processes where RNA plays a central role, and are important factors in cell differentiation and development (Lüking et al. 1998). The Vasa gene was identified for the first time in Drosophila as a maternal-effect gene, being essential for germ cell lineage development and for proper abdomen specification (Hay et al. 1990). Vasa homologs reported from different species have also been revealed as essential genes for the development of the germ cell lineage, although they show some important differences in their regulation (Raz 2000).

The Vasa gene was the first molecular marker employed for the identification of primordial germ cells (PGCs) in fish (Yoon et al. 1997). It has also been used as a marker of testicular germ cell transplantation in flatfish species (Pacchiarini et al. 2013a). Vasa regulatory regions have been used to control the expression of transgenes, and thus to monitor PGC migration in living fish species (Krøvel \& Olsen 2002) as well as to isolate PGCs from fish (Fan et al. 2008). In this sense, it was thought that Vasa expression in fish was restricted to germ cell lineage, however Vasa extragonadal expression has been reported in several fish species, such as Oncorhynchus mykiss (Yoshizaki et al. 2000), Dicentrarchus labrax (Blázquez et al. 2011) and Solea senegalensis (Pacchiarini et al. 2013b). Many studies have reported levels and pattern changes of Vasa expression during embryogenesis, sex differentiation and larval development in various fish species (Yoon et al. 1997, Krøvel \& Olsen 2004, Xu et al. 2005, Li et al. 2010, Raghuveer \& Senthilkumaran 2010, Cao et al. 2012, Lin et al. 2012, Pacchiarini et al. 2013a,b), showing a differential expression during oogenesis and spermatogenesis (Cao et al. 2012). Different Vasa transcripts with different expression patterns have also been characterized in diverse fish species, such as zebrafish, tilapia and Senegalese sole (Yoon et al. 1997, Kobayashi et al. 2002, Pacchiarini et al. 2013b), and the Vasa gene is usually present as a single copy gene in the majority of chordates, e.g. in zebrafish (Krøvel \& Olsen 2004). However, recently, Fujimura et al. (2011) reported 3 Vasa gene loci in the genome of tilapia.

The present study aimed to identify the Vasa homologue from Lusitanian toadfish in a first molecular and cellular approach, using its mRNA and cDNA for quantitative and qualitative gene expres- sion in histological sections of testis, ovary, and several somatic organs and tissues. We also used a specific Vasa antibody to test for protein distribution in parallel histological sections of both gonads from adult toadfish specimens.

\section{MATERIALS AND METHODS}

\section{Biological samples}

The toadfish $(\mathrm{n}=10)$ were caught in the Bay of Cadiz (SW Spain) from natural populations in September 2011 and May 2012. The specimens ranged from 285 to $420 \mathrm{~mm}$ total length and from 628 to $1527 \mathrm{~g}$ total weight; the population sex ratio was close to $1: 1$ as previously described by Palazón-Fernández et al. (2001). After anesthetizing with 1500 ppm phenoxyethanol (Sigma), the fish were decapitated according to REGA-ES110280000311 animal welfare procedures (ICMAN-CSIC). The organs and tissues (ovary, testis, heart, brain, muscle, liver, gill, intestine, swim bladder, spleen and kidney) were extracted and frozen immediately in liquid nitrogen, and stored at $-80^{\circ} \mathrm{C}$ until used.

Gonad samples for in situ hybridization (ISH) and immunohistochemical (IHC) techniques were fixed with $4 \%$ paraformaldehyde in diethyl pyrocarbonate- (DEPC) treated phosphate-buffered salineTween20 (PBST) solution overnight at $4^{\circ} \mathrm{C}$ and stored in methanol at $-20^{\circ} \mathrm{C}$ after washing 3 times for $1 \mathrm{~h}$ with PBST, and then processed according to ÚbedaManzanaro et al. (2014). Histomorphological and cell characterization in both male and female gonads was performed by haematoxylin-eosin and haematoxylinVOF stainings.

\section{Nucleic acid extraction, cloning and phylogenetic analysis of Vasa products}

Total RNA was extracted from 100 mg of each tissue sample using TriReagent (Sigma) and DNA contamination was removed using DNase I (Fermentas), as previously described in Úbeda-Manzanaro et al. (2014). The concentration and quality of the RNA was determined by UV spectrophotometry (A260:A280 nm ratios $>1.7$ ), and total RNA integrity was measured by electrophoresis on $1 \%$ agarose-formaldehyde gel.

First-strand cDNA was synthesized using the SMARTer RACE cDNA Amplification Kit (Clontech), according to the manufacturer's instructions. To isolate a full-length cDNA sequence of Vasa, 5'- and 3'- 
Table 1. Primers used for the sequencing and quantification of Vasa mRNA levels in Halobatrachus didactylus. E: efficiency ( $\mathrm{E}=1$ is $100 \%$ efficiency)

\begin{tabular}{|lllc|}
\hline Primer & Sequence $\left(5^{\prime} \rightarrow 3^{\prime}\right)$ & Application & $\mathrm{R}^{2}$ \\
\hline VAF1 & GGG ACT TGT GTG CGT CCA GTA GTG G & $3^{\prime}$-RACE & \\
VAF2 & GGT GGA GTC AGC ACC GGA CAC CAA & $3^{\prime}$-nested RACE & \\
VASARv & TTG GTG TCC GGT GCT GAC TCC ACC & $5^{\prime}$-RACE & \\
VASARvN & CAA CAA CTG GCC GCA CAC AAG TCC C & $5^{\prime}$-nested RACE & \multirow{2}{*}{0.9988} \\
OLIGOVAF & ACA GGC CAT AAT GAC TTT TGC TGA & qPCR \& ISH & 0.9908 \\
OLIGOVAR & AGG AAT GCA GCC GTT TTA CCA & qPCR \& ISH & 0.9956 \\
EFF & CCG GTA TCT CCA AGA ACG GAC & qPCR & 1.0269 \\
EFR & GCT CAC CTC CTT GTT GAT CTC A & qPCR & \\
\hline
\end{tabular}

rapid amplification of cDNA ends were performed with specific and nested primers (Table 1), designed from sequence alignment of teleost orthologs using ClustalW (www.genome.jp/tools/clustalw/). The amplification procedures were carried out in a Doppio thermocycler (VWR) according to the manufacturer's instructions, with modifications in the thermal cycling. The PCR products were purified and inserted into a pGEM-T Easy Vector System (Promega). The positive clones were sequenced at the Sequencing Service from Biomedal (Spain), and the different obtained sequences were assembled using BioEdit 7.0.9.0. (Hall 1999).

The putative amino acid sequence of the main Vasa protein product was deduced using a translate tool (http://web.expasy.org/translate/), and was aligned with other sequences from the DEAX-box protein family with ClustalW algorithm. The molecular phylogenetic analysis was conducted using the neighborjoining method (Saitou \& Nei 1987) with MEGA 5.1 software (Tamura et al. 2011). Bootstrap resampling (Felsenstein 1985) was applied to assess support for individual nodes using 10000 replicates, and evolutionary distances were computed using the Poisson correction method (Zuckerkandl \& Pauling 1965), uniform rates among sites, and complete option treatment of gaps and missing data. Branches with very low bootstrap confidence values were collapsed. The Genbank accession numbers of these sequences are provided in Table S1 in the Supplement at www.intres.com/articles/suppl/b021p037_supp.pdf.

\section{Quantitative PCR}

Total RNA $(1 \mu \mathrm{g})$ was reverse-transcribed into cDNA using the iScript ${ }^{\mathrm{TM}}$ cDNA Synthesis Kit (BioRad) according to the manufacturer's instructions. Vasa expression was analyzed by quantitative PCR (qPCR) in a Mastercycler ${ }^{\circledR}$ ep realplex ${ }^{2} \mathrm{~S}$ (Eppen- dorf), in a final volume of $10 \mu \mathrm{l}$ containing $1 \mu \mathrm{l}$ of a 1/10 dilution of cDNA, SsoFast ${ }^{\mathrm{TM}}$ EvaGreen ${ }^{\circledR}$ Supermix (BioRad), and $300 \mathrm{nM}$ of each specific primer, OLIGOVAF and OLIGOVAR (Table 1). qPCR was run for 35 cycles $\left(95^{\circ} \mathrm{C}\right.$ for $15 \mathrm{~s}, 64^{\circ} \mathrm{C}$ for $15 \mathrm{~s}$ and $72^{\circ} \mathrm{C}$ for $20 \mathrm{~s}$ ). The products were verified by sequencing, and melting-curve analysis was performed for each sample to check single amplification. As the internal control, elongation factor 1 alpha (ef1- $\alpha$ ) gene was amplified from the same set of cDNA samples using the primers EFF and EFR (Table 1). Relative quantification was performed using the 2(-Delta Delta C(T)) method described previously (Livak \& Schmittgen 2001), using the gill as a calibrator sample. Five biological replicates of each sample were analyzed, and each PCR was performed in parallel with a technical duplicate. Negative qPCR controls using doubledistilled water instead of cDNA were included in the assays for each primer pair.

To identify statistically significant differences in Vasa tissue distribution by qPCR, 1-way ANOVA was employed, followed by a Student-Newman-Keuls (SNK) post hoc test, using SSPS 15.0 software (IBM). In each case, differences were accepted as statistically significant at $\mathrm{p}<0.05$.

\section{ISH using Vasa sense and antisense riboprobes}

RNA in situ hybridizations using digoxigenin (DIG)-labeled antisense and sense riboprobes were performed as recently described by Úbeda-Manzanaro et al. (2014) on histological sections of toadfish testes and ovaries, using $55^{\circ} \mathrm{C}$ as the temperature of hybridization. The Vasa sense and antisense riboprobes were generated from a 177-bp fragment (Table 1) cloned into pCRII Dual Promoter vector (Invitrogen). The RNA probes were produced from $1 \mu \mathrm{g}$ of linearized plasmid using T7 (sense) or SP6 (antisense) polymerases. 


\section{IHC detection of Vasa protein}

A specific toadfish anti-Vasa antibody was synthesized and tested by adequate controls (Wester, ELISA) by Biomedal. This specific antibody was designed to localize 16 amino acids (IHGDREQREREQALKD) in the toadfish Vasa protein.

IHC was performed according to ÚbedaManzanaro et al. (2014). In parallel histological sections, preimmunized rabbit serum was used as a negative control.

\section{RESULTS}

\section{Toadfish Vasa cDNA and phylogeny analysis}

The full-length cDNA of the toadfish Vasa gene was $2347 \mathrm{bp}$, and has been deposited in the NCBI database with the accession number JX849133 (see Fig. S1 in the Supplement at www.int-res.com/articles/suppl/b021p037_ supp.pdf). This sequence is comprised of an open reading frame of $1845 \mathrm{bp}$, a 5'- untranslated region (5'-UTR) of $131 \mathrm{bp}$, and a 3'-UTR of $371 \mathrm{bp}$ with a poly(A) tail. Moreover, minority products were also isolated from testes and ovaries by 5 '- and 3'-RACE (Genbank accession numbers JX849136-JX849142; see Fig. S2 in the Supplement). These minority products showed deletions/insertions in the arginine/glycine (R/G)-rich N-terminal region or in the $\mathrm{C}$-terminal region.

Phylogenetic analysis using a neighborjoining method (Fig. 1) grouped the proteins according to the protein sub-family. Toadfish Vasa protein was clustered within other teleost fish Vasa homologues apart from other vertebrates. Interestingly, the tree suggests that toadfish Vasa homologue is more closely related to Vasa homologues from fish species of the superorden Acanthopterygii than of Paracanthopterygii.

\section{Vasa mRNA expression and Vasa protein distribution}

Tissue analysis by qPCR showed that the Vasa gene was expressed in all studied organs and tissues (Fig. 2). The highest Vasa mRNA expression levels were found in the

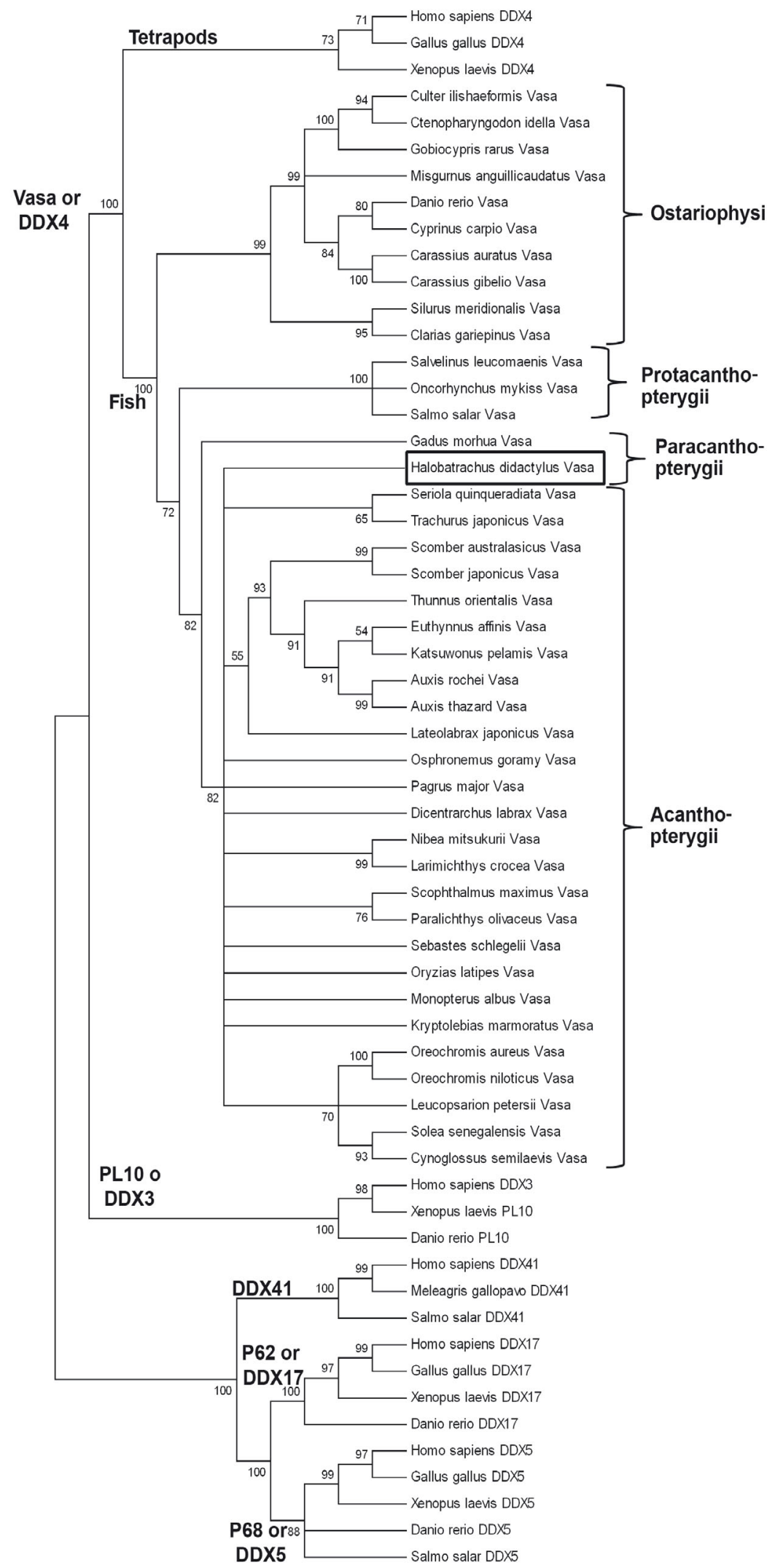

Fig. 1. Phylogenetic tree of DEAD-box proteins using the neighborjoining method with MEGA 5.1 


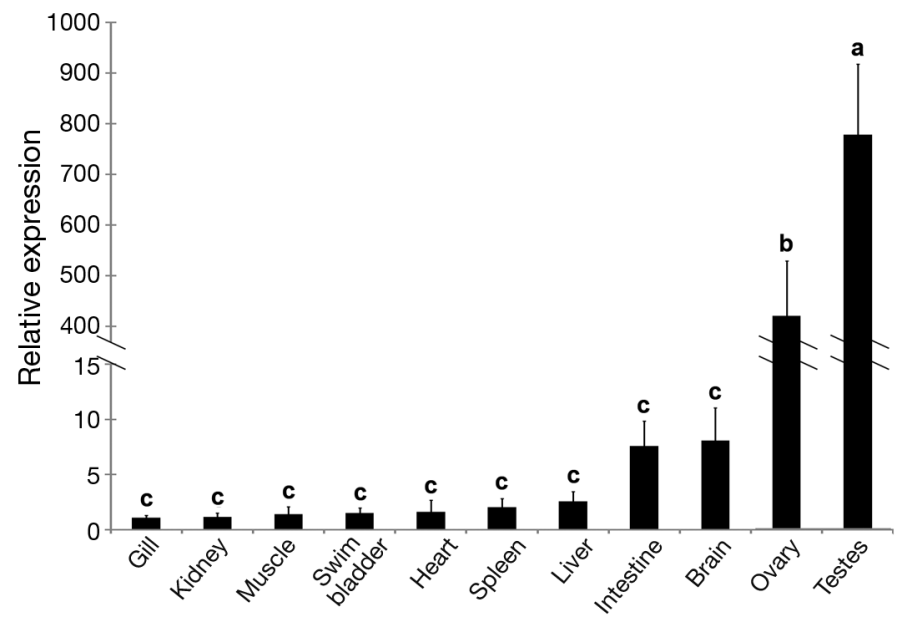

Fig. 2. Relative expression levels of Vasa mRNA in adult Lusitanian toadfish organs and tissues (mean $\pm \mathrm{SE}, \mathrm{n}=5$ ). Statistically significant differences (lower case letters: $a, b$, and c) were detected by ANOVA, SNK post hoc test, $\mathrm{p}<0.05$

testes, followed by the ovaries. Relatively low mRNA expression levels were reported in the heart, liver, spleen, kidney, swim bladder, intestine, muscle, gill and brain tissues.

ISH was used to determine the pattern of toadfish Vasa expression during gametogenesis in testis and ovary tissues from adult toadfish specimens (Fig. 3). In the testes, the antisense Vasa riboprobe showed signals in germ cells (specifically in spermatogonia, spermatocytes and spermatids). In the ovaries, the Vasa mRNA was localized in the cytoplasm of early vitellogenic oocytes, being cortically concentrated within the cytoplasm of advanced vitellogenic oocytes. A very weak Vasa expression was detected in oogonia at nuclear localization, and no Vasa mRNA expression was evidenced in previtellogenic oocytes. No detectable signal was observed using the sense probe.

IHC showed the presence of Vasa protein in the cytoplasm of spermatogonia, spermatocytes and spermatids in testis. The ovary showed strong Vasa protein immunosignals in the cytoplasm of oogonia and previtellogenic oocytes, whereas Vasa immunostaining became weaker as the vitellogenesis and maturation processes progressed (Fig. 4).

\section{DISCUSSION}

The Vasa gene, which encodes a DEAD-box RNA helicase, is the molecular marker of germ cells most documented in teleosts (Lin et al. 2012), because it shows high specificity, is widely conserved through- out the animal kingdom, and it is relatively easy to detect (Cao et al. 2012). The characterization of Vasa cDNA in Lusitanian toadfish showed a major product whose predicted protein is 615 aa long. This product contains the 8 consensus motifs of the DEAD-box protein family, and the absence of mutation in the ATP-A motif (AXXXXGKT), the ATP-B motif (DEAD), the RNA unwinding motif (SAT) and the RNA binding motif (HRIGRXXR) reveal its functionality as a helicase (Pause \& Sonenberg 1992).

Different transcripts of Vasa homologues have been reported in various fish species, such as Oreochromis niloticus (Kobayashi et al. 2002), Danio rerio (Bártfai \& Orbán 2003, Krøvel \& Olsen 2004), Gobiocyprus rarus (Cao et al. 2012), Solea senegalensis (Pacchiarini et al. 2013b) and Scopththalmus maximus (Lin et al. 2012, Pacchiarini et al. 2013a). A single copy of the Vasa gene is the most frequent condition among vertebrates, although different isoforms can be expressed (Castrillon et al. 2000, Krøvel \& Olsen 2004). However, Fujimura et al. (2011) reported 3 Vasa loci in Oreochromis niloticus (Nile tilapia), unlike other closely related East African cichlids, suggesting a lineage-specific duplication of the Vasa gene during the evolution of Nile tilapia. Among the minority Vasa products observed in the Lusitanian toadfish, the coding sequence showed up to 6 different variants (JX849136-JX849140) in the N-terminal region, which contains the arginine/glycine-rich repeats. RGG and GRG motifs have a role as a site of arginine methylation, which is an important posttranslational modification that regulates proteinprotein interactions (Kirino et al. 2010). Wolke et al. (2002) suggested that the RGG repeats have also been implicated in subcellular localization of the Vasa protein in zebrafish. The high variability of the RGG-rich region observed in Lusitanian toadfish could be due to multiple alternative splicing, which suggests high variability in Vasa mRNA processing that may contribute to regulate the activity of the different Vasa transcripts. The variability in the Cterminal region of minority Vasa products was only identified from toadfish ovarian samples. One of these variants (JX849142) showed a 221 nucleotide deletion with respect to the standard Vasa sequence, resulting in the loss of the functional domains VII and VIII (Lüking et al. 1998). As a consequence, this product could not perform the specific activity of RNA-helicase and could have been generated by an abnormal or inefficient biogenesis of mRNA. The other Vasa variant (JX849141) contained all consensus motifs of the DEAD-box proteins, but lacked the conserved tryptophan (W), glutamic acid 

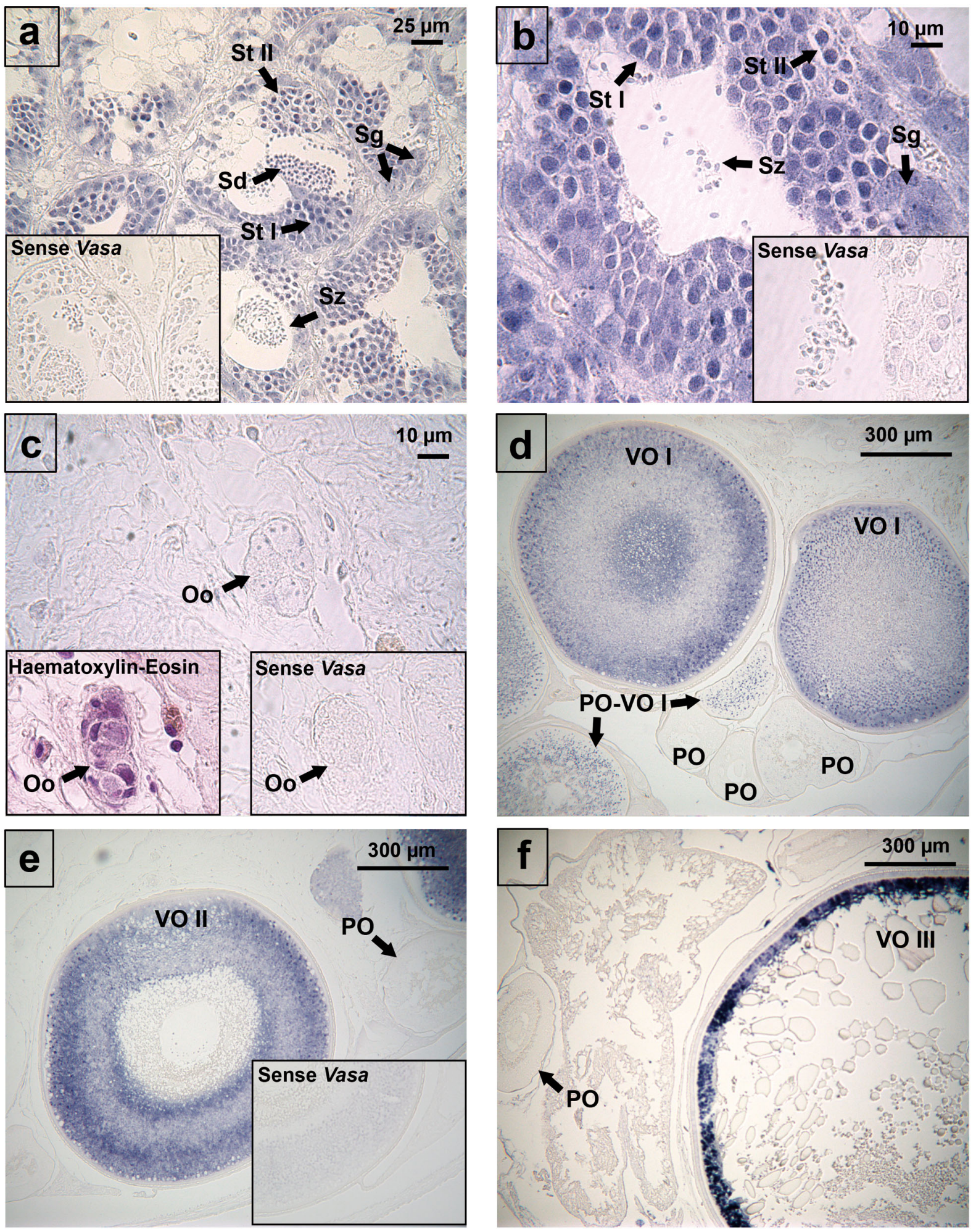

Fig. 3. In situ hybridization (ISH) analysis of Vasa mRNA expression in gonad sections of Lusitanian toadfish: (a,b) antisense Vasa probe showing expression in spermatogonia (Sg), spermatocytes (St) type I and II, and spermatids (Sd); (c-f) ovarian expression of Vasa in cytoplasm of vitellogenic oocytes (VO) type I, II and III. Faint signals were observed in nuclear localization in oogonia (Oo). No signals were observed in spermatozoa (Sz) and in previtellogenic oocytes (PO). Sense controls in testis and in ovary sections are included in the lower right corner of images (a), (b), (c) and (e). An image of histological section of ovary including oogonia stained with haematoxylin-eosin is included in the lower left corner of image (c) 

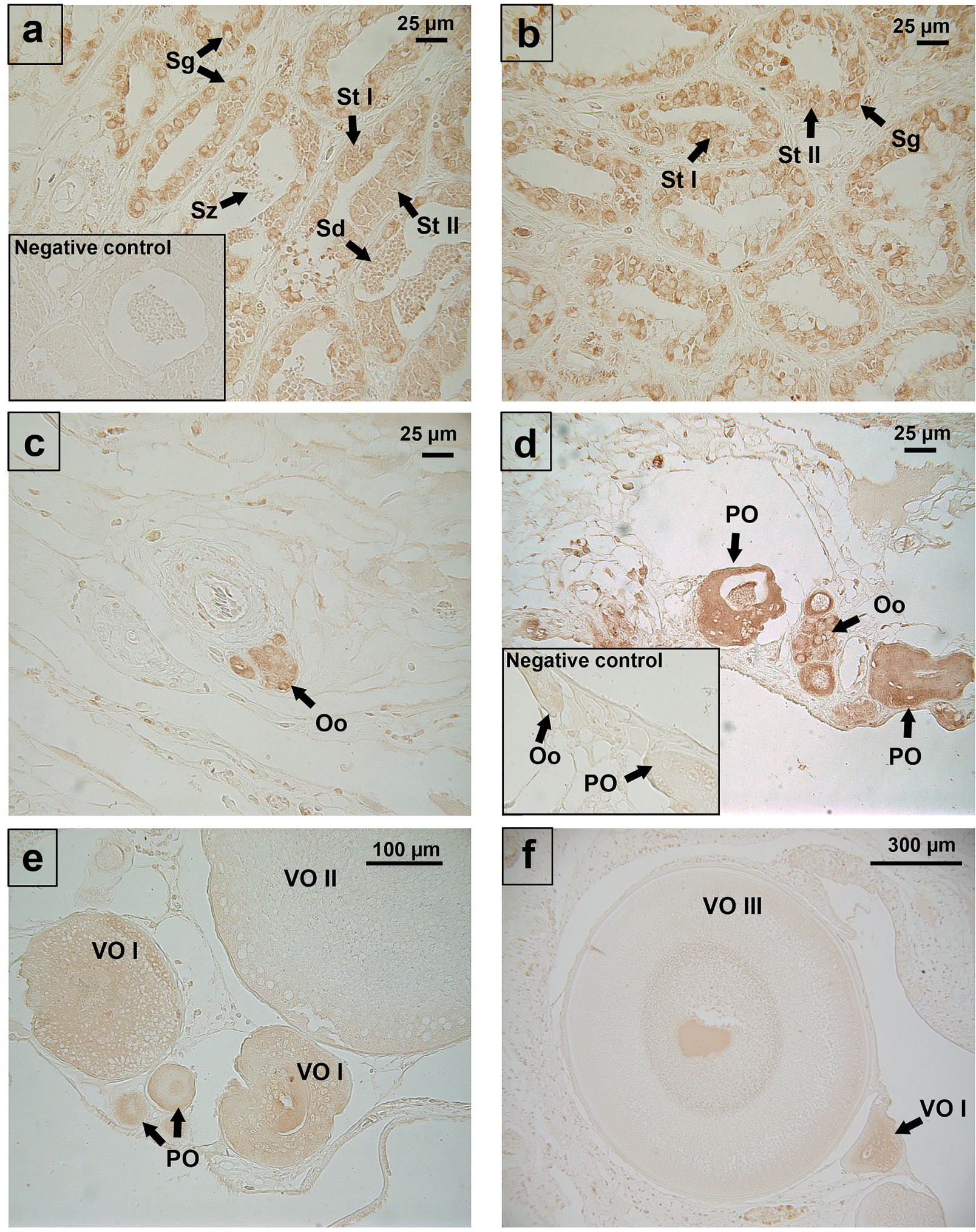

VO III

Fig. 4. Immunohistochemical (IHC) localization of Vasa protein in gonads sections of Lusitanian toadfish: (a,b) testicular localization of Vasa protein in spermatogonia (Sg), spermatocytes (St) type I and II, and spermatids (Sd) of testis. No signals were observed in spermatozoa (Sz). (c-f) IHC showing strong signals of Vasa protein in oogonia (Oo) and previtellogenic oocytes (PO). The signal becomes weaker in vitellogenic oocytes (VO) type I, II and III. Control sections incubated with preimmune rabbit serum from testis and ovary were included in the lower left corner of images (a) and (d), respectively 
(E) and aspartic acid (D) residues in the C-terminal region; it also lacked the 3'-UTR, although it has a stop codon immediately upstream of the poly-A. Yao et al. (2012) suggested a general mechanism for production of $\mathrm{C}$ terminus-truncated regulatory proteins generated by polyadenylation-directed conversion of a tyrosine codon in the coding sequence to a stop codon, and this Vasa transcript (JX849141) could have been generated by a similar mechanism. However, further studies are required to confirm whether toadfish Vasa is a single copy gene or not, and also to investigate the function of different transcripts, if any.

The tissue expression profile of the Vasa gene in adult toadfish was performed by qPCR without differentiating between the transcripts, because most of these transcripts showed minimal molecular differences. Vasa expression was principally restricted to the gonads, in agreement with the role of Vasa as a translational regulator in germinal line development (Braat et al. 1999a), and as in other adult fish species (Xu et al. 2005, Ye et al. 2007, Nagasawa et al. 2009, Li et al. 2010, Blázquez et al. 2011, Cao et al. 2012, Lin et al. 2012, Presslauer et al. 2012, Xiao et al. 2013). However, the Vasa gene could also be involved in the regulation of translation of certain mRNA, which is essential for the specification of somatic cells where Vasa protein is present (Ikenishi \& Tanaka 2000). In particular, new functions of Vasa have been described in the regulation of the cell cycle in multipotent cells and tumoral cells (Gustafson \& Wessel 2010, Yajima \& Wessel 2011). As in the Lusitanian toadfish, relatively low extragonadal expression levels of the Vasa gene have been reported in different fish species (Yoshizaki et al. 2000, Blázquez et al. 2011, Pacchiarini et al. 2013b), involving diverse unknown roles and functions so far. Sexual dimorphic expression patterns of the different Vasa transcripts have been reported in some teleost fish, and a switch between the Vasa transcripts was also observed during embryonic and larval development of several fish species, suggesting that relative expression of different Vasa transcripts could be involved in sexual differentiation and/or dimorphism in these teleost species (Kobayashi et al. 2002, Krøvel \& Olsen 2004, Pacchiarini et al. 2013b). Recently, a switch was reported in Solea senegalensis between the longest Vasa transcripts, which are maternally supplied, and the shortest Vasa transcripts, which are expressed de novo during the growing larvae before sexual differentiation (Pacchiarini et al. 2013b).
Different cellular distribution patterns of Vasa mRNA in gonads have been revealed in different fish species by ISH. In toadfish testes, the expression pattern of Vasa gene showing positive signals in spermatogonia, spermatocytes and spermatids was similar to the cellular distribution pattern reported in Senegalese sole (Pacchiarini et al. 2013b). However, in most fish species, Vasa gene expression was observed only in spermatogonia and spermatocytes (Kobayashi et al. 2000, Xu et al. 2005, Ye et al. 2007, Cao et al. 2012, Lin et al. 2012, Xiao et al. 2013, Pacchiarini et al. 2013a), whereas in bluefin tuna Vasa mRNA was restricted to spermatogonia only (Nagasawa et al. 2009).

Vasa gene expression during oogenesis is a very dynamic process with respect to expression levels and cellular distribution. In many fish species, Vasa mRNA ISH signals are most intense in oogonia and early vitellogenic oocytes, decreasing in more advanced vitellogenenic stages (Braat et al. 1999b, Xu et al. 2005, Nagasawa et al. 2009, Lin et al. 2012, Ye at al. 2007, Pacchiarini et al. 2013a,b). The low levels of Vasa mRNA in oogonia from toadfish ovaries contrast to the high levels of Vasa protein, which could indicate that the translation of Vasa mRNA is differentially regulated in selfrenewing germ stem cells and differentiating germ cells by meiosis, as suggested by Xu et al. (2005) in Carassius auratus gibelio. However, the absence of Vasa mRNA in the previtellogenic oocytes of Halobatrachus didactylus and Sparus aurata (Cardinali et al. 2004) could be due to the low levels of Vasa transcripts in this early stage of oogenesis in both fish species. The increased expression of Vasa mRNA in vitellogenic oocytes of Lusitanian toadfish suggests that the accumulation of Vasa maternal factor could happen when starting vitellogenesis, and also suggests a potential regulatory role for Vasa in oocyte maturation, as was suggested in tilapia (Kobayashi et al. 2000) and sea bream (Cardinali et al. 2004). On the other hand, the presence of Vasa protein in oogonia and previtellogenic oocytes could suggest an active role in the early stages of oogenesis, and the weak immunosignals observed in maturing oocytes of $H$. didactylus could be explained by Vasa-diluting within the total protein content of these advanced maturating oocytes. The Vasa protein may be considered a useful marker for germ cell lineage, which has an important role during gametogenesis (oogenesis and spermatogenesis), and for sex determination or sexual dimorphism of Lusitanian toadfish. 


\section{CONCLUSIONS}

The Vasa homologue identified in Lusitanian toadfish was predominantly expressed in the gonads, resulting a good sex cell marker. However, other Vasa transcripts have also been identified, and the Vasa gene could be functionally involved in other physiological processes. The present study provides information useful for future research of developmental sex mechanisms, such as studies on the different Vasa transcripts and their expression, variations during the annual reproductive cycle and during sexual determination, and differentiation.

Acknowledgements. The authors are grateful to Isabel Viaña and Dr. José Luis Palazón (ICMAN-CSIC) for their technical assistance and help in the collection and processing of biological samples. This work was financed by Proyecto de Excelencia (RNM-03074; Consejería de Innovación, Ciencia y Empresa, Junta de Andalucía, Spain). M.Ú-M. was supported by a CSIC JAE-Predoc fellowship.

\section{LITERATURE CITED}

Bártfai R, Orbán L (2003) The vasa locus in zebrafish: multiple RGG boxes from duplications. DNA Cell Biol 22: 47-54

> Blázquez M, González A, Mylonas CC, Piferrer F (2011) Cloning and sequence analysis of a vasa homologue in the European sea bass (Dicentrarchus labrax): tissue distribution and mRNA expression levels during early development and sex differentiation. Gen Comp Endocrinol 170:322-333

Borges G, Mendonça P, Joaquim N, Coucelo J, Aureliano M (2003) Acute effects of vanadate oligomers on heart, kidney, and liver histology in the Lusitanian toadfish (Halobatrachus didactylus). Arch Environ Contam Toxicol 45: 415-422

Braat AK, Speksnijder JE, Zivkovic D (1999a) Germ line development in fishes. Int J Dev Biol 43:745-760

> Braat AK, Zandbergen T, van de Water S, Goos HJ, Zivkovic D (1999b) Characterization of zebrafish primordial germ cells: morphology and early distribution of vasa RNA. Dev Dyn 216:153-167

> Campana O, Sarasquete C, Blasco J (2003) Effect of lead on ALA-D activity, metallothionein levels, and lipid peroxidation in blood, kidney, and liver of the toadfish Halobatrachus didactylus. Ecotoxicol Environ Saf 55:116-125

Cao M, Yang Y, Xu H, Duan J and others (2012) Germ cell specific expression of Vasa in rare minnow, Gobiocypris rarus. Comp Biochem Physiol A Mol Integr Physiol 162: 163-170

> Cardinali M, Gioacchini G, Candiani S, Pestarino M, Yoshizaki G, Carnevali O (2004) Hormonal regulation of Vasa-like messenger RNA expression in the ovary of the marine teleost Sparus aurata. Biol Reprod 70:737-743

Castrillon DH, Quade BJ, Wang TY, Quigley C, Crum CP (2000) The human VASA gene is specifically expressed in the germ cell lineage. Proc Natl Acad Sci USA 97: 9585-9590
Desantis S, Cirillo F, Deflorio M, Megalofonou P, Palazón JL, Sarasquete C, De Metrio G (2007) Histochemical study of glycoconjugates in the toadfish Halobatrachus didactylus oesophagus epithelium. Histol Histopathol 22:23-35

Fan L, Moon J, Wong TT, Crodian J, Collodi P (2008) Zebrafish primordial germ cell cultures derived from vasa::RFP transgenic embryos. Stem Cells Dev 17:585-597

Felsenstein J (1985) Confidence limits on phylogenies: an approach using the bootstrap. Evolution 39:783-791

Fujimura K, Conte MA, Kocher TD (2011) Circular DNA 5 intermediate in the duplication of Nile tilapia vasa genes. PLoS ONE 6:e29477

Greenfield DW, Winterbottom R, Collette BB (2008) Review of the toadfish genera (Teleostei: Batrachoididae). Proc Calif Acad Sci 59:665-710

> Gustafson EA, Wessel GM (2010) Vasa genes: emerging roles in the germ line and in multipotent cells. Bioessays 32:626-637

Hall TA (1999) BioEdit: a user-friendly biological sequence alignment editor and analysis program for Windows 95/98/NT. Nucleic Acids Symp Ser (Oxf) 41:95-98

> Hay B, Jan LY, Jan YN (1990) Localization of vasa, a component of Drosophila polar granules, in maternal-effect mutants that alter embryonic anteroposterior polarity. Development 109:425-433

> Ikenishi K, Tanaka TS (2000) Spatio-temporal expression of Xenopus vasa homolog, XVLG1, in oocytes and embryos: the presence of XVLG1 RNA in somatic cells as well as germline cells. Dev Growth Differ 42:95-103

Kirino Y, Vourekas A, Kim N, de Lima Alves F and others (2010) Arginine methylation of Vasa protein is conserved across phyla. J Biol Chem 285:8148-8154

Kobayashi T, Kajiura-Kobayashi H, Nagahama Y (2000) Differential expression of vasa homologue gene in the germ cells during oogenesis and spermatogenesis in a teleost fish, tilapia, Oreochromis niloticus. Mech Dev 99:139-142

$>$ Kobayashi T, Kajiura-Kobayashi H, Nagahama Y (2002) Two isoforms of vasa homologs in a teleost fish: their differential expression during germ cell differentiation. Mech Dev 111:167-171

> Krøvel AV, Olsen LC (2002) Expression of a vas::EGFP transgene in primordial germ cells of the zebrafish. Mech Dev 116:141-150

> Krøvel AV, Olsen LC (2004) Sexual dimorphic expression pattern of a splice variant of zebrafish vasa during gonadal development. Dev Biol 271:190-197

> Li CJ, Liu L, Chen XH, Zhang T, Gan F, Cheng BL (2010) Identification of a Vasa homologue gene in grass carp and its expression pattern in tissues and during embryogenesis. Comp Biochem Physiol B Biochem Mol Biol 157: 159-166

> Lin F, Xu S, Ma D, Xiao Z and others (2012) Germ line specific expression of a vasa homologue gene in turbot (Scophthalmus maximus): evidence for vasa localization at cleavage furrows in euteleostei. Mol Reprod Dev 79: 803-813

Livak KJ, Schmittgen TD (2001) Analysis of relative gene expression data using real-time quantitative PCR and the 2 (-Delta Delta C(T)) method. Methods 25:402-408

> Lüking A, Stahl U, Schmidt U (1998) The protein family of RNA helicases. Crit Rev Biochem Mol Biol 33:259-296

> Merlo A, Cross I, Palazón JL, Sarasquete C, Rebordinos L (2007) Chromosomal mapping of the major and minor ribosomal genes, (GATA) $)_{n}$ and (TTAGGG) by one-color 
and double color FISH in the toadfish Halobatrachus didactylus (Teleostei: Batrachoididae). Genetica 131: 195-200

Modesto T, Canário AV (2003) Morphometric changes and sex steroid levels during the annual reproductive cycle of the Lusitanian toadfish, Halobatrachus didactylus. Gen Comp Endocrinol 131:220-231

- Nagasawa K, Takeuchi Y, Miwa M, Higuchi K and others (2009) cDNA cloning and expression analysis of a vasalike gene in Pacific bluefin tuna Thunnus orientalis. Fish Sci 75:71-79

Pacchiarini T, Sarasquete C, Cabrita E (2013a) Development of interspecies testicular germ-cell transplantation in flatfish. Reprod Fertil Dev, doi:10.1071/RD13103

Pacchiarini T, Cross I, Leite RB, Gavaia P and others (2013b) Solea senegalensis vasa transcripts: molecular characterisation, tissue distribution and developmental expression profiles. Reprod Fertil Dev 25:646-660

Palazón-Fernández JL, Arias AM, Sarasquete C (2001) Aspects of the reproductive biology of the toadfish, Halobatrachus didactylus (Schneider, 1801) (Pisces: Batrachoididae). Sci Mar 65:131-138

Palazón-Fernández JL, Peiro Suso M, Mancera JM, Sarasquete C (2011) Immunohistochemical study of the principal pancreatic islet of the toadfish, Halobatrachus didactylus (Pisces: Batrachoididae). Acta Histochem 113: 256-261

Pause A, Sonenberg N (1992) Mutational analysis of a DEAD box RNA helicase: the mammalian translation initiation factor eIF-4A. EMBO J 11:2643-2654

Presslauer C, Nagasawa K, Fernandes JM, Babiak I (2012) Expression of vasa and nanos3 during primordial germ cell formation and migration in Atlantic cod (Gadus morhua L.). Theriogenology 78:1262-1277

Raghuveer K, Senthilkumaran B (2010) Cloning and differential expression pattern of vasa in the developing and recrudescing gonads of catfish, Clarias gariepinus. Comp Biochem Physiol A Mol Integr Physiol 157:79-85

Raz E (2000) The function and regulation of vasa-like genes in germ-cell development. Genome Biol 1:reviews1017.11017.6

Saitou N, Nei M (1987) The neighbour-joining method: a new method for reconstructing phylogenetic trees. Mol Biol Evol 4:406-425

Soares SS, Martins H, Gutiérrez-Merino C, Aureliano M (2008) Vanadium and cadmium in vivo effects in teleost cardiac muscle: metal accumulation and oxidative stress markers. Comp Biochem Physiol Part C Toxicol Pharmacol 147:168-178

Tamura K, Peterson D, Peterson N, Stecher G, Nei M, Kumar

Editorial responsibility: Roderick Finn,

Bergen, Norway
S (2011) MEGA5: molecular evolutionary genetics analysis using maximum likelihood, evolutionary distance, and maximum parsimony methods. Mol Biol Evol 28: 2731-2739

Úbeda-Manzanaro M, Merlo MA, Ortiz-Delgado JB, Rebordinos L, Sarasquete C (2014) Expression profiling of the sex-related gene Dmrt1 in adults of the Lusitanian toadfish Halobatrachus didactylus (Bloch and Schneider, 1801). Gene 535:255-265

> Vasconcelos RO, Sisneros JA, Amorim MC, Fonseca PJ (2011) Auditory saccular sensitivity of the vocal Lusitanian toadfish: low frequency tuning allows acoustic communication throughout the year. J Comp Physiol A Neuroethol Sens Neural Behav Physiol 197:903-913

> Wolke U, Weidinger G, Koprunner M, Raz E (2002) Multiple levels of posttranscriptional control lead to germ linespecific gene expression in the zebrafish. Curr Biol 12: 289-294

Xiao J, Luo Y, Chen L, Yang L and others (2013) Molecular cloning of vasa gene and the effects of LHRH-A on its expression in blue tilapia Oreochromis aureus. Fish Physiol Biochem 39:931-940

> Xu H, Gui J, Hong Y (2005) Differential expression of vasa RNA and protein during spermatogenesis and oogenesis in the gibel carp (Carassius auratus gibelio), a bisexually and gynogenetically reproducing vertebrate. Dev Dyn 233:872-882

Yajima M, Wessel GM (2011) The multiple hats of Vasa: its functions in the germline and in cell cycle progression. Mol Reprod Dev 78:861-867

Yao P, Potdar AA, Arif A, Ray PS and others (2012) Coding region polyadenylation generates a truncated tRNA synthetase that counters translation repression. Cell 149: 88-100

> Ye D, Lv D, Song P, Peng M and others (2007) Cloning and characterization of a rice field eel vasa-like gene cDNA and its expression in gonads during natural sex transformation. Biochem Genet 45:211-224

Yoon C, Kawakami K, Hopkins N (1997) Zebrafish vasa homologue RNA is localized to the cleavage planes of 2and 4-cell-stage embryos and is expressed in the primordial germ cells. Development 124:3157-3165

> Yoshizaki G, Sakatani S, Tominaga H, Takeuchi T (2000) Cloning and characterization of a vasa-like gene in rainbow trout and its expression in the germ cell lineage. Mol Reprod Dev 55:364-371

Zuckerkandl E, Pauling L (1965) Evolutionary divergence and convergence in proteins. In: Bryson V, Vogel HJ (eds) Evolving genes and proteins. Academic Press, New York, NY, p 97-166

Submitted: January 8, 2014; Accepted: March 20, 2014 Proofs received from author(s)May 26, 2014 